\title{
Effects of food quality on naupliar development in Calanus glacialis at subzero temperatures
}

\author{
Malin Daase $^{1,2, *}$, Janne E. Søreide ${ }^{1}$, Daria Martynova ${ }^{3}$ \\ ${ }^{1}$ The University Centre in Svalbard, PO Box 156, 9171 Longyearbyen, Norway \\ ${ }^{2}$ Norwegian Polar Institute, Polar Environment Centre, 9296 Tromsø, Norway \\ ${ }^{3}$ Zoological Institute, Russian Academy of Sciences, St. Petersburg 199034, Russia
}

\begin{abstract}
We studied the naupliar development of the calanoid copepod Calanus glacialis, a key herbivore in the Arctic marine ecosystem. Eggs obtained from females collected at $78^{\circ} \mathrm{N}$ in Svalbard, Norway, in May 2008 were reared at $-1.2^{\circ} \mathrm{C}$ in a temperature-controlled room. Stage-specific naupliar development time, survival and naupliar size were studied in response to different food qualities, i.e. low versus high proportions of polyunsaturated fatty acids (PUFAs) and low versus high element molar ratios (C:N and C:P). Length measurements of consecutive naupliar stages were obtained from image analysis of digital photos taken every second day. A length-frequency analysis revealed distinct size classes for each stage. Stage duration of the 6 naupliar stages varied between 6 and 27 d. The longest stage duration was measured for Stage NIII. Development time from hatching to Stage NVI was shortest (41.9 d) for nauplii reared under high algal bloom chlorophyll a (chl a) concentra-

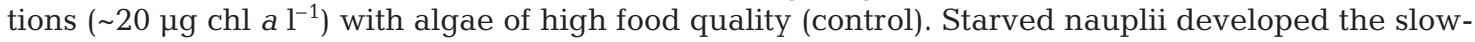
est and showed highest mortality. High mortality was also recorded for nauplii fed with algae grown under a phosphorous limitation that were offered at the same chl a concentrations as the control treatment. These algae had lower PUFA concentrations and higher element molar ratios and were, thus, of lower food quality than the control algae. However, comparable development times and naupliar sizes were found for nauplii fed with algae of high or low food quality. This is the first study that successfully follows the entire naupliar development of Calanus glacialis at subzero temperatures.
\end{abstract}

KEY WORDS: Naupliar development $\cdot$ Temperature $\cdot$ Food quality $\cdot$ Naupliar size

\section{INTRODUCTION}

The calanoid copepods of the genus Calanus account for up to $80 \%$ of the zooplankton biomass in Arctic and sub-Arctic seas, and thus constitute the key trophic link between primary producers and higher trophic levels in the Arctic marine ecosystems (Hop et al. 2006, Blachowiak-Samolyk et al. 2008, Falk-Petersen et al. 2009). Of 3 co-occurring Calanus species, C. hyperboreus, C. glacialis and C. finmarchicus, C. glacialis is by far the most important in the cold shelf seas in the European Arctic (Conover \& Huntley 1991, Kosobokova et al. 1998, Søreide et al. 2008).

Calanus glacialis has a 1 to 3 year life cycle with Stages CIV and CV as the main overwintering stages
(Conover 1988, Scott et al. 2000, Arnkvaern et al. 2005). C. glacialis is primarily herbivorous, although protists may be part of their diet (Levinsen et al. 2000). Essential polyunsaturated fatty acids (PUFAs) from the algal diet are accumulated by C. glacialis, and lowenergy carbohydrates and proteins from algae are converted into high-energy wax ester lipids (Lee 1975, Scott et al. 2002). These lipid reserves sustain the organisms during periods of limited food supply (Lee 1974, Sargent \& Falk-Petersen 1988) and fuel early reproduction, allowing the offspring to develop to the first feeding naupliar stage by the onset of the phytoplankton bloom (Hirche \& Kattner 1993, Niehoff et al. 2002, Hirche \& Kosobokova 2003, Lee et al. 2006, Søreide et al. 2010). This life history strategy is consid- 
ered an adaptation to the short and unpredictable productive season at high latitudes in ice-covered waters (Conover \& Huntley 1991, Falk-Petersen et al. 2009).

Calanus glacialis reproduction and naupliar growth normally take place in ice-covered seas at water temperatures close to the freezing point of seawater $\left(-1.8^{\circ} \mathrm{C}\right.$ at salinity 34.8$)$. Data on $C$. glacialis naupliar development times are, however, scarce and to our knowledge only Corkett et al. (1986) and McLaren et al. (1988) have estimated the development time of $C$. glacialis nauplii. Naupliar development times have been studied in other Calanus species, such as the North Atlantic species C. finmarchicus (Hygum et al. 2000, Campbell et al. 2001, Cook et al. 2007), C. hyperboreus (Corkett et al. 1986) and C. helgolandicus (Cook et al. 2007, Bonnet et al. 2009), as well as $C$. pacificus (Mullin \& Brooks 1970a, Landry 1983), C. sinicus (Uye 1988), C. australis (Peterson \& Painting 1990) and C. marshallae (Peterson 1986). However, these rearing experiments have been conducted at temperatures well above $0^{\circ} \mathrm{C}\left(2\right.$ to $\left.20^{\circ} \mathrm{C}\right)$, and measurements of development time of any Calanus species in water temperatures close to the freezing point of seawater are not available.

The development time of copepods is mainly controlled by temperature (McLaren \& Corkett 1981, Peterson 2001), but food quality and quantity are also regulating factors. Starvation can reduce survival (Lopez 1996), and low food concentrations increase development times of different Calanus species as well as the variability in development time among individuals (Mullin \& Brooks 1970a, Campbell et al. 2001, Cook et al. 2007). However, naupliar development appears to be less sensitive to food limitations than copepodite development (Hart 1990, Hirst \& Lampitt 1998, Hygum et al. 2000). Food quality is another important regulating factor for naupliar development (Huntley et al. 1987, Rey et al. 2001). For instance the morphology of the algae may affect their digestibility (e.g. presence of indigestible features around the cell, Jónasdóttir 1994, Koski et al. 1998) or the size of the algal cells may make them unsuitable as a food item for nauplii (Rey et al. 2001, Cook et al. 2007). Furthermore, the biochemical composition of the algae may affect naupliar development owing to either the presence of inhibitory compounds (Carotenuto et al. 2002, Ianora et al. 2004) or the lack of certain nutritional components essential for the copepod's development (Hessen 1992, Klein Breteler et al. 2005).

PUFAs and, in particular, the long-chained omega-3 fatty acids eicosapentaenoic acid (EPA) and docosahexaenoic acid (DHA), which are produced exclusively by marine algae, play a key role in reproduction, growth and physiology for all marine organisms (Ack- man 1989). The importance of omega-3 fatty acids for copepod egg production, egg hatching and zooplankton growth has been well documented in field (Pond et al. 1996, Jónasdóttir et al. 2005) and experimental (Klein Breteler et al. 2005, Jónasdóttir et al. 2009) studies. Insufficient dietary supplies of nitrogen $(\mathrm{N})$ and phosphorus (P) can also limit growth and reproduction in copepods. Herbivorous consumers generally have higher mass-specific $\mathrm{N}$ and $\mathrm{P}$ contents than that of their algal food, and thus their growth rate may be limited by a shortage of these elements (Hessen 1992). Algae of 'high' food quality are thus usually characterised by an elevated PUFA content as well as low C:N and C:P ratios (Brett \& Müller-Navarra 1997, Klein Breteler et al. 2005).

In the present study we investigated naupliar development time and survival of Calanus glacialis at subzero temperatures. Nauplii were reared under starvation or fed algae of different food qualities as defined by differences in their PUFA content as well as C:N and C:P ratios.

\section{MATERIALS AND METHODS}

Experimental set-up. Mature Calanus glacialis females were collected in Isfjorden (Svalbard, $78^{\circ} \mathrm{N}, 13^{\circ} \mathrm{E}$ ) on 11 May 2008 by vertical hauls (0 to $50 \mathrm{~m}$ ) with a WP3 net (mesh size, $1 \mathrm{~mm}$; mouth opening, $1.0 \mathrm{~m}^{2}$ ) with a large, non-filtering cod end. The female copepods were incubated at $-1.2^{\circ} \mathrm{C}$ in large containers that had a false bottom of $300 \mu \mathrm{m}$ mesh size and were fed surplus algal food (Thalassiosira sp.) to promote high egg production rates.

Naupliar development. Eggs produced from 13 to 14 May were kept and placed in several Petri dishes filled with filtered seawater. The nauplii that hatched on 19 and 20 May were collected and kept for the rearing experiment (nauplii hatched on 19 or 20 May were not mixed). The development of these nauplii was carefully followed and when the first NIII naupliar stage appeared (the first feeding stage), the copepods were transferred to 11 plastic bottles, and incubations with 2 different algal food qualities and one starved treatment (filtered seawater, FSW) began (Table 1). One hundred nauplii were placed in each bottle, except in the starved treatment where 50 nauplii were added per bottle. Five replicates were set up for each treatment. Nauplii fed with algae of either high or poor food quality were offered the same diatom species - a monoculture of Thalassiosira cf. nordenskioeldii (cell size, 10 to $15 \mu \mathrm{m})$-in the same concentrations (Table 2), which is comparable with the maximum chlorophyll $a(\mathrm{chl} a$ ) values at the peak of the spring

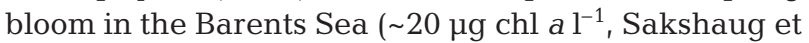


Table 1. Calanus glacialis. Number of individuals in each replicate of each of the 3 treatments at the start and end of the experiments, and number of individuals that developed to Stage NVI in each replicate. Replicates of the phosphate-limited treatment (P-lim) and filtered seawater treatment (FSW) were merged when fewer than 5 individuals were left in each replicate; thus number of nauplii at end of experiment is not available for each treatment and replicate

\begin{tabular}{|c|c|c|c|c|c|c|c|c|c|}
\hline \multirow{2}{*}{$\begin{array}{l}\text { Replicate } \\
\text { no. }\end{array}$} & \multicolumn{3}{|c|}{ Control -} & \multicolumn{3}{|c|}{ P-lim } & \multicolumn{3}{|c|}{ FSW } \\
\hline & Start & End & NVI & Start & End & NVI & Start & End & NVI \\
\hline 1 & 100 & 14 & 6 & 100 & 8 & 3 & 100 & 4 & 1 \\
\hline 2 & 100 & 20 & 11 & 100 & - & - & 50 & - & - \\
\hline 3 & 100 & 18 & 4 & 100 & - & - & 50 & - & - \\
\hline 4 & 100 & 23 & 8 & 100 & - & - & 50 & - & - \\
\hline 5 & 100 & $33^{a}$ & 19 & $100^{\mathrm{b}}$ & - & - & 50 & 3 & - \\
\hline $2+3+4^{\mathrm{c}}$ & - & - & - & - & 5 & 2 & - & 9 & 2 \\
\hline Total & 500 & 108 & 48 & 500 & 13 & 5 & 300 & 16 & 3 \\
\hline
\end{tabular}

al. 2009). Differences in food qualities were promoted by growing the algae with different $\mathrm{P}$ concentrations (see below).

The bottles were kept in a slowly rotating plankton wheel in a temperature-controlled cooling laboratory. The temperature during the course of the experiment was, on average, $-1.2 \pm 0.38^{\circ} \mathrm{C}$ (mean $\pm \mathrm{SD}$ ) and ranged from -1.7 to $-0.5^{\circ} \mathrm{C}$, and the experiment was run in darkness. Every second day the water and algal food suspension was renewed by gently pouring the suspension through a fine mesh sieve halfway submerged in seawater to collect the nauplii. The nauplii were kept for a short while in Petri dishes filled with filtered seawater before they were gently returned to the experimental bottles they came from, which were

Table 2. Mean \pm SE algae cell numbers, chl $a, C, N$ and $\mathrm{P}$ concentrations, C:N and C:P ratios and the proportion of saturated (SAFA), monounsaturated (MUFA) and polyunsaturated (PUFA) fatty acids in control and phosphate limited (P-lim) algal cultures. The proportions of the PUFAs, eicosapentaenoic acid (EPA) and docosahexaenoic acid (DHA) are also given. An asterisk ( $\left.{ }^{*}\right)$ after a value indicates a significant dif-

ference from the control for that feature $(t$-tests: $p<0.05)$

\begin{tabular}{|c|c|c|}
\hline Feature & Control & P-lim \\
\hline No. algal cells $1^{-1}$ & $1019.7 \pm 83.3$ & $1012.4 \pm 82.2$ \\
\hline Chl a $\left(\mu g \mathrm{l}^{-1}\right)$ & $17.3 \pm 1.2$ & $22.7 \pm 1.3$ \\
\hline$C\left(\mu g \mathrm{l}^{-1}\right)$ & $349.9 \pm 53.9$ & $1355.5 \pm 99.1^{*}$ \\
\hline $\mathrm{N}\left(\mu \mathrm{g} \mathrm{l}^{-1}\right)$ & $68.1 \pm 5.0$ & $144.4 \pm 16.9^{*}$ \\
\hline$P\left(\mu g l^{-1}\right)$ & $22.2 \pm 2.5$ & $17.8 \pm 1.0$ \\
\hline C:N (molar ratio) & $5.9 \pm 0.7$ & $11.6 \pm 0.8^{*}$ \\
\hline C:P (molar ratio) & $40.7 \pm 5.5$ & $196.5 \pm 6.9^{*}$ \\
\hline Lipids $\left(\mathrm{mg} \mathrm{l}^{-1}\right)$ & $0.7 \pm 0.1$ & $1.3 \pm 0.1^{*}$ \\
\hline$\%$ SAFA & $40.1 \pm 4.7$ & $40.8 \pm 1.1$ \\
\hline$\%$ MUFA & $13.6 \pm 0.6$ & $26.9 \pm 0.6^{*}$ \\
\hline$\%$ PUFA & $46.3 \pm 5.2$ & $32.3 \pm 1.5^{*}$ \\
\hline$\%$ 20:5n-3 (EPA) & $22.0 \pm 2.8$ & $15.6 \pm 0.5$ \\
\hline$\%$ 22:6n-3 (DHA) & $2.5 \pm 0.3$ & $1.3 \pm 0.1^{*}$ \\
\hline
\end{tabular}

filled with fresh food suspensions or renewed filtered seawater. The experiment was terminated 1 July 2008, $42 \mathrm{~d}$ after eggs hatched. However, 33 Stage NVI nauplii from the control treatment (Table 1) were kept for an additional week to estimate the development time from Stage NIV to Stage CI.

Algal food. Two different algal food treatments were applied, both consisting of the same Thalassiosira sp. monoculture (Thalassiosira cf. nordenskioeldii), a single-celled culture with cell sizes between 10 and $15 \mu \mathrm{m}$. To achieve 2 different algal food qualities from the same monoculture, the monoculture was cultivated with 2 different nutrient enrichment solutions. Growing algae in nutrient enrichment solutions with one limiting nutrient, either $\mathrm{P}$ or $\mathrm{N}$, can cause a skewed uptake of $\mathrm{C}$ relative to $\mathrm{P}$ (or $\mathrm{N}$ ), which leads to an accumulation of C-rich compounds and thus high C:P (or $\mathrm{C}: \mathrm{N})$ ratios and lower food quality of the algae (Berman-Frank \& Dubinsky 1999, Hessen et al. 2002). Growth is generally equivalent to protein synthesis, where $\mathrm{P}$-rich ribosomes and $\mathrm{N}$-rich amino acids are the key macromolecules. The $\mathrm{C}: \mathrm{P}$ and/or $\mathrm{C}: \mathrm{N}$ algal ratios become higher with increasing nutrient imbalance (i.e. ratios of $\mathrm{C}$ to nutrients) (Hessen et al. 2002). Autotrophs have a much larger flexibility in their $\mathrm{C}: \mathrm{N}: \mathrm{P}$ ratios in contrast to the consumers' rather strict $\mathrm{C}: \mathrm{N}: \mathrm{P}$ ratios (Hessen et al. 2004). The C:P or C:N ratios of autotrophs are commonly far above those of their consumers, and this stoichiometric mismatch may have profound effects on the efficiency of the energy flow in food webs. If a high rate of $\mathrm{C}$ fixation via photosynthesis is not met by a corresponding increase in uptake of $\mathrm{N}$ and $\mathrm{P}$, autotroph biomass with low nutrient value (high C:N or C:P) will result, which causes poor growth in consumers (e.g Hessen \& Faafeng 2000). Nutrient imbalance leads to less efficient C-fixation and poorer growth in algae that again leads to lower algal PUFA content (Klein Breteler et al. 2005). By cultivating the 
algal food with 2 different nutrient enrichments, one with limited P (P-lim) and one with no limiting nutrients (control) we aimed to get 2 different algal food treatments independent of algal species and algal cell size.

The control was grown in filtered (GF/F) seawater enriched with Guillard's (F/2) marine water enrich-

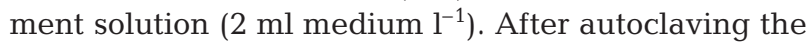
$\mathrm{F} / 2$ medium to prevent contamination of the diatom monoculture, $1 \mathrm{ml} \mathrm{l}^{-1}$ silicate solution $\left(7.5 \mu \mathrm{mol} \mathrm{Si}(\mathrm{OH})_{4}\right.$ $\mathrm{l}^{-1}$ ) was added. The P-lim culture was grown in autoclaved artificial seawater free of phosphate, enriched with $1 \mathrm{ml} \mathrm{l}^{-1}$ silicate solution $\left(7.5 \mu \mathrm{mol} \mathrm{Si}(\mathrm{OH})_{4} \mathrm{l}^{-1}\right)$ and a medium similar to Guillard's (F/2) marine water enrichment solution, although at a phosphate concentration approximately 15 times weaker (i.e. $0.598 \mu \mathrm{mol}$ $\mathrm{PO}_{4}^{-} \mathrm{l}^{-1}$ ). Both cultures were grown in 101 Nalgene bottles with air bubbled into them. The cultures were kept in incubator chambers at temperatures of $\sim{ }^{\circ} \mathrm{C}$, exposed to light intensities of $\sim 100 \mu \mathrm{mol} \mathrm{m}{ }^{-2}$ in a $14 \mathrm{~h}$ light:10 h dark cycle. The cultures were diluted every second day.

Algal food concentrations. To obtain similar food concentrations in the 2 algal food treatments, the densities of algal cells in the 2 cultures were counted with a haemacytometer as described in Guillard (1978) and Schoen (1988), and the appropriate dilution rates with filtered seawater were calculated.

The chl a concentration of the final algal suspensions offered to copepods in each of the 2 treatments was measured every second day. Parallel samples of $100 \mathrm{ml}$ were filtered on GF/C glass fiber filters and stored frozen at $-20^{\circ} \mathrm{C}$ until they were analysed 4 mo later. $\mathrm{Chl}$ a was analysed fluorometrically with methanol as the extracting solvent (Holm-Hansen \& Rieman 1978).

Fatty acid analysis. Every second day samples of $100 \mathrm{ml}$ from each algal culture were filtered onto precombusted glass fibre filters $(\mathrm{GF} / \mathrm{F})$ for total lipid fatty acid composition. The filters were transferred to glass vials with Teflon-lined caps, and $8 \mathrm{ml}$ dichloromethane-methanol $(2: 1, \mathrm{v} / \mathrm{v})$ was added. The vials were stored at $-80^{\circ} \mathrm{C}$ until analyses. Total lipid was extracted according to the procedure described in Folch et al. (1957). A known amount of heneicosanoic acid (21:0) was added as internal standard, and an acid-catalysed transesterification was carried out with $1 \%$ sulfuric acid in methanol (Christie 1982). The extract was then cleaned in a silica column. The relative composition of the fatty acid methyl esters (FAME) was determined by means of a gas chromatograph (Agilent $6890 \mathrm{~N}$ ) equipped with a fused silica, wallcoated capillary column $(50 \mathrm{~m} \times 0.25 \mathrm{~mm}$ inside diameter, Varian Select FAME), with an oven thermal gradient from an initial $60^{\circ} \mathrm{C}$ to $150^{\circ} \mathrm{C}$ at a rate of $30^{\circ} \mathrm{C}$ $\mathrm{min}^{-1}$, and then to a final temperature of $230^{\circ} \mathrm{C}$ at $1.5^{\circ} \mathrm{C}$ $\mathrm{min}^{-1}$. Individual components were identified by comparison with 4 known standards (2 gas-liquid chromatography [GLC] reference mixtures from $\mathrm{Nu}-\mathrm{Chek}$ Prep [GLC 96 and GLC 68 D] and 2 standards from Sigma-Aldrich [Supelco ${ }^{\circledR} 37$ Component FAME MIX and PUFA No.3 from menhaden oil]) and were quantified by means of HPChemStation software (HewlettPackard).

Elemental stoichiometry. Samples for analysis of particulate $\mathrm{C}, \mathrm{N}$ and $\mathrm{P}$ were taken every second day on the same dates as the fatty acid samples. Water volumes of $50 \mathrm{ml}$ were filtered onto precombusted GF/F filters. The $\mathrm{C}$ and $\mathrm{N}$ filter samples were stored in the plastic Petri dishes, whereas P filter samples were stored in acid-washed plastic bottles. All the samples were stored at $-20^{\circ} \mathrm{C}$ until analysis. Particulate $\mathrm{C}$ and $\mathrm{N}$ were analysed on an elemental analyser (Leeman Lab). To measure particulate $P$ the filters were first placed into $15 \mathrm{ml}$ distilled acidified water $(150 \mu \mathrm{l}, 4.0 \mathrm{M}$ $\left.\mathrm{H}_{2} \mathrm{SO}_{4}\right)$ to which peroxodisulfate $\left(0.15 \mathrm{~g} \mathrm{~K}_{2} \mathrm{~S}_{2} \mathrm{O}_{8}\right)$ was added, and the samples were then autoclaved. The particulate fraction of $\mathrm{P}$ was analysed spectrophotometrically by the standard ammonium-molybdate method (Hessen et al. 2002).

Naupliar length measurement and size classes. Every second day digital photos were taken of 10 to 15 nauplii, selected randomly from 1 to 3 replicates of each treatment, with a digital video camera (Sony HDR-HC7E) mounted to a stereomicroscope at $40 \times$ magnification. This was done when the nauplii were removed from the experimental bottles to renew the water and food (see above). Nauplii were kept in a Petri dish filled with filtered seawater, which was then placed under the stereomicroscope to take the digital photos. The stereomicroscope was located in a cooling room at $3^{\circ} \mathrm{C}$. All nauplii were replaced in their experimental bottles after being photographed. Length measurements of nauplii were done with ImageJ 1.42q, a graphics program freely available on the internet (http://rsbweb.nih.gov/ij).

The length of nauplii was measured from the top of the cephalothorax to the end of the naupliar body. Because the bodies of nauplii in Stages III to VI are curved, 2 measurements were recorded for those nauplii that appeared bent on the image: the first from the top to the end of the cephalosome, and the second from the end of the cephalosome to the end of the naupliar body. These measurements added together constitute the total length of the nauplius.

Size classes were retrieved from length-frequency data by means of mixture distribution analysis (MacDonald \& Pitcher 1979) with the 'mixdist' package as part of the R-environment software (www.r-project. org). The goodness of fit was indicated by chi-square test statistics and cohorts in the length-frequency dis- 
tribution were considered as size classes. The program was run in an interactive mode, by stepwise optimising of the relative abundance (proportions), means and variances of cohorts.

To avoid stress and rough handling of the nauplii we did not attempt to determine the stage of living nauplii. Instead we used the size classes derived from the length-frequency analysis to determine the stage of each nauplius that we digitally photographed.

Development time. Stage-specific development times and stage durations were calculated from observed changes in the stage frequency (cumulative frequencies) with time by means of the method of median development time (MDT) (Landry 1983, Peterson \& Painting 1990). We estimated MDT based on the relative stage composition derived from the digital photographs taken every second day for each treatment. MDT to a specific stage was defined as the time when $50 \%$ of the population had moulted to that stage (Landry 1983, Peterson \& Painting 1990, Hygum et al. 2000, Rey et al. 2001). MDT was estimated from linear regression of the proportion of the population that had completed a given moult versus time (Landry 1983, Peterson \& Painting 1990). Proportional data were arcsine root transformed before the regression analysis (Sokal \& Rohlf 1995).

Mortality rates. The daily per capita mortality rates $(M)$ of the nauplii were estimated by the relationship:

$$
M=\left\{\ln \left[n\left(t_{1}\right)\right]-\ln \left[n\left(t_{2}\right)\right]\right\} / t_{2}-t_{1}
$$

(Aksnes et al. 1997), where $n(t)$ is the total abundance of nauplii at time $t$. The number of nauplii in each replicate was counted every second day starting from Day 16 after hatching. This was done while the water in the experimental bottles was renewed (see above). Nauplii were kept in a Petri dish filled with filtered seawater and counted under a stereomicroscope located in the cooling laboratory. Lines were fitted to log-transformed naupliar abundance in each replicate versus time by simple linear regression. As the population was closed, the slopes of the regression lines can be interpreted as per capita mortality rates. Percentage daily mortality $(\mathrm{PDM})$ is given by $\left(1-\mathrm{e}^{-M}\right) \times 100$.

\section{RESULTS}

\section{Algal food quality and concentrations}

No differences in cell densities and chl a concentrations were found between the 2 food treatments: control and P-lim (Table 2). The proportion of PUFAs, however, was $14 \%$ higher in the control than in the
P-lim treatment (Table 2). In terms of elemental stoichiometry P-lim had almost twice as high $\mathrm{C}: \mathrm{N}$ ratios and 6 times higher C:P ratios than the control (Table 2). This was due to the much higher $\mathrm{C}$ and $\mathrm{N}$ contents in P-lim versus the control, whereas comparable P content was recorded in the 2 treatments (Table 2). In terms of food quality P-lim was of significant lower quality than the control diet mainly owing to its imbalance in nutrients (i.e. high C:P and C:N ratios), but also because of its lower proportions of PUFAs.

\section{Naupliar development}

Development time from one naupliar stage to the next varied between 6 and $27 \mathrm{~d}$ depending on stage and food quality (Table 3, Fig. 1a). The longest stage duration was observed for Stage NIII in all treatments. The control treatment was the only treatment for which enough data were available to calculate the development time for all naupliar stages (Table 3). In this treatment, one-third $(33.7 \%)$ of the development time from hatching to Stage CI was spent as NIII (Table 3). Nauplii reared in the control developed faster than those kept without food supply (FSW), and $108(21 \%)$ out of 500 individuals initially survived until the end of the experiment (Table 1). Forty-eight individuals reached Stage NVI; 33 of these were kept and of these 7 individuals reached Stage CI. Median development time from hatching to Stage CI was calculated to be $51 \mathrm{~d}$ (Table 3$)$.

Nauplii fed algae grown under P-lim conditions developed as fast as those in the control treatment (Table 3). However, their mortality was high (Table 4), as only $13(2.6 \%)$ of initially 500 individuals survived to the end of the experiment and only 5 individuals reached Stage NVI (Table 1). Nauplii kept under FSW conditions developed slowly (Table 3, Fig. 1a), 
and only 3 individuals (1\%) developed into Stage NVI (Table 1). Of initially 300 nauplii in FSW only 16 individuals $(4.3 \%)$ survived until the end of the experiment.
For the period of 13 June to 1 July, $M$ (Table 4) differed significantly among treatments (1-way ANOVA: $F=16.089, \mathrm{df}=12, \mathrm{p}<0.001)$. Discrepancies were mainly due to significant differences between the con- a

50

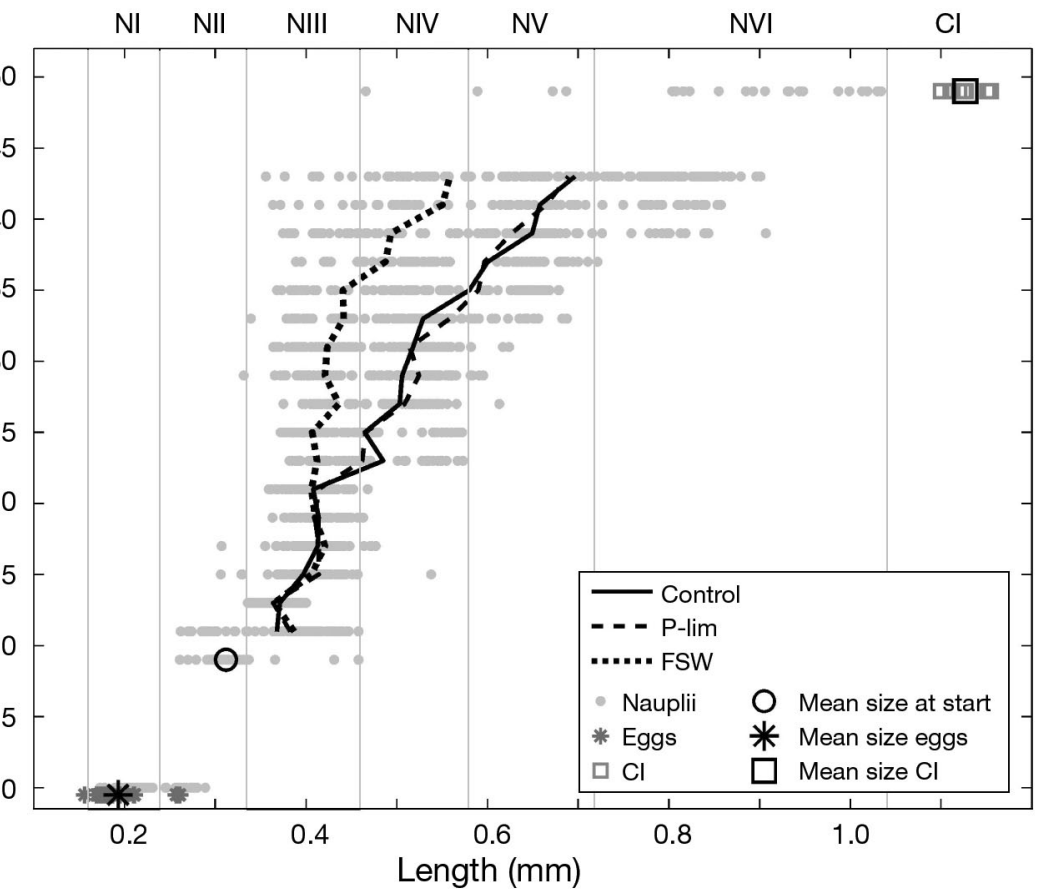

b

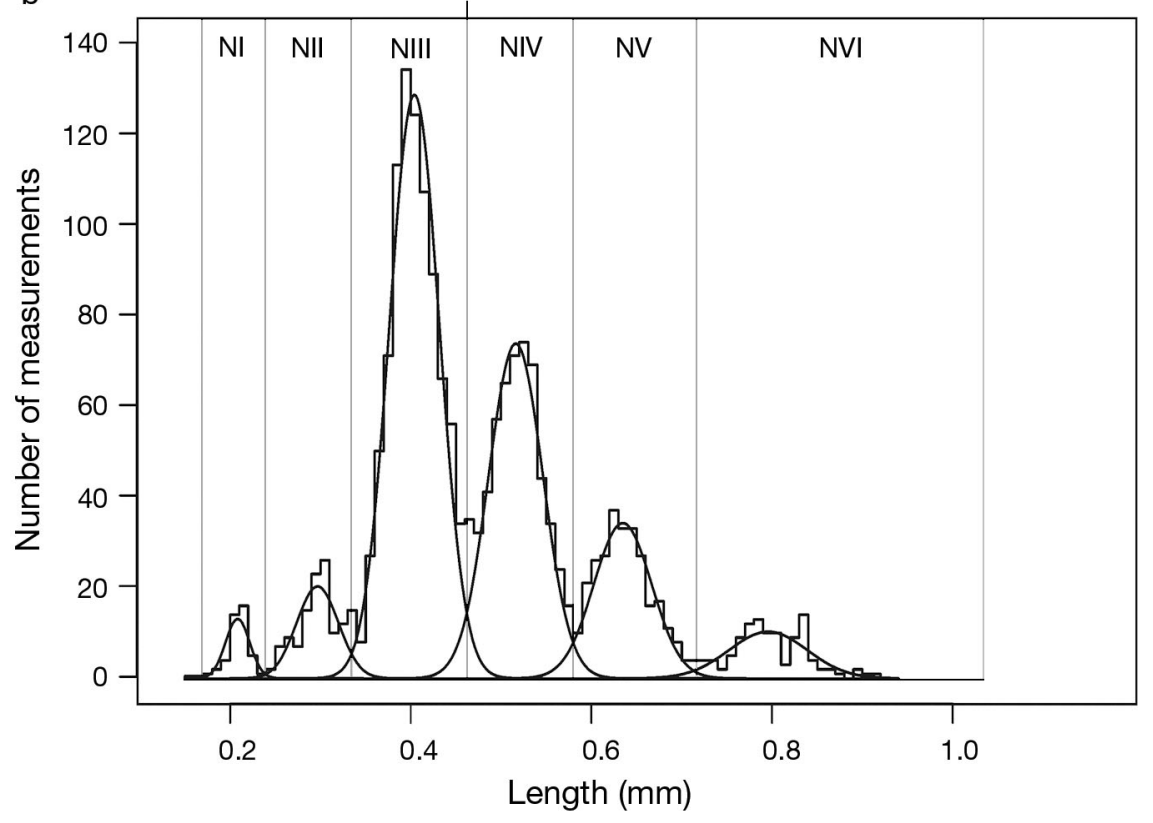

C
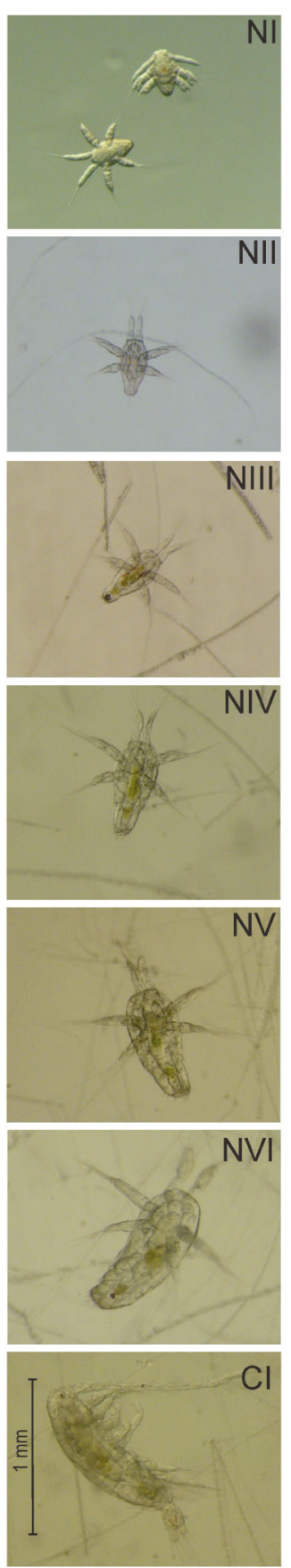

Fig. 1. Calanus glacialis. (a) Sizes of eggs (diameter, grey asterisks), naupliar Stages NI to NVI (total length, grey dots) and copepodite Stage I (prosome length, grey squares). Lines show mean length of nauplii in the 3 experimental treatments measured at a specific day after hatching. Grey lines in the background indicate the length classes for each consecutive naupliar stage calculated from length-frequency analysis (MIX analysis) of the naupliar stages presented in (b) (see 'Materials and methods' for details). (c) Digital photographs of naupliar Stages NI to NVI and copepodite Stage CI. All photographs are shown at the same scale. P-lim: phosphate limited; FSW: filtered seawater 
Table 4. Calanus glacialis. Daily per capita mortality rate $(M)$ and percent daily mortality (PDM) of nauplii for each replicate of each treatment and the mean for each treatment. P-lim: phosphate limited; FSW: filtered sea water

\begin{tabular}{|lcccccc|}
\hline Replicate & \multicolumn{2}{c}{ Control } & \multicolumn{2}{c|}{$\begin{array}{c}\text { P-lim } \\
M\left(\mathrm{~d}^{-1}\right)\end{array}$} & PDM $(\%)$ & \multicolumn{2}{c|}{$\begin{array}{c}\text { FSW } \\
\left(\mathrm{d}^{-1}\right)\end{array}$} & PDM $(\%)$ & $M\left(\mathrm{~d}^{-1}\right)$ & PDM $(\%)$ \\
\hline R1 & 0.07 & 6.5 & 0.07 & 6.4 & 0.14 & 12.9 \\
R2 & 0.03 & 2.5 & 0.14 & 13.1 & 0.15 & 13.8 \\
R3 & 0.04 & 4.0 & 0.17 & 15.2 & 0.11 & 10.2 \\
R4 & 0.04 & 3.5 & 0.19 & 17.0 & 0.12 & 11.2 \\
R5 & 0.04 & 4.3 & 0.16 & 14.5 & 0.11 & 10.8 \\
Mean & 0.04 & 4.4 & 0.14 & 15.4 & 0.13 & 13.3 \\
\hline
\end{tabular}

Table 5. Calanus glacialis. Size classes $(\mathrm{mm})$ of successive naupliar stages for each treatment and for all measurements combined, based on analysis of length-frequency distribution derived from total length measurements taken from digital photographs. P-lim: phosphate limited; FSW: filtered sea water; nd: no data

\begin{tabular}{|lcccccc|}
\hline & \multicolumn{7}{c|}{ Naupliar stage } \\
& NI & NII & NIII & NIV & NV & NVI \\
\hline Control & nd & nd & $0.35-0.48$ & $0.49-0.58$ & $0.59-0.72$ & $>0.73$ \\
P-lim & nd & nd & $0.35-0.48$ & $0.49-0.58$ & $0.59-0.72$ & $>0.73$ \\
FSW & nd & nd & $0.35-0.46$ & $0.47-0.56$ & $0.57-0.71$ & $>0.72$ \\
All & $<0.24$ & $0.25-0.34$ & $0.35-0.47$ & $0.48-0.58$ & $0.59-0.72$ & $>0.725$ \\
\hline
\end{tabular}

trol and FSW and P-lim treatments (Tukey's HSD: p < 0.05), whereas variability in $M$ between FSW and P-lim was not significant. Nauplii in the control treatment experienced the lowest mortality rates $(0.03$ to $0.07 \mathrm{~d}^{-1}$, Table 4). The highest mortality rates were observed for nauplii in P-lim (0.07 to $\left.0.19 \mathrm{~d}^{-1}\right)$ and for starved nauplii (FSW) ( 0.11 to $\left.0.15 \mathrm{~d}^{-1}\right) . M$ varied from an average of $4.4 \%$ for nauplii in the control to $>13 \%$ for nauplii in P-lim and FSW (Table 4).

\section{Naupliar size classes}

A length-frequency analysis revealed distinct size classes for each naupliar stage (Table 5, Fig. 1b). Sizes varied between the different treatments (Fig. 2). In particular the median size of Stage NIV nauplii in the FSW treatment was much smaller than those in the other treatments. However, variations were high and sizes in the different treatments overlapped for most stages (Fig. 2). Size classes based on measurement of nauplii from all treatments were therefore established (Table 5).

Only a few measurements were obtained of Stages NIV and NV in the FSW treatment and of Stage NVI in the P-lim treatment; therefore, the analysis of these data has to be treated with caution.

\section{DISCUSSION}

\section{Development time}

The development time of Calanus glacialis nauplii was not isochronal, i.e. the naupliar stage durations were not of equal time duration. Landry (1983) concluded that isochronal development was not a general characteristic of copepod development. Isochronal development has not been observed in either $C$. finmarchicus (Campbell et al. 2001) or C. pacificus (Landry 1983), and it appears to be less common in copepods that accumulate large lipid reserves (Campbell et al. 2001).

Other aspects of the early life history of Calanus glacialis agreed with generalizations made by Landry (1983) and Peterson (2001), such as having short pre-feeding stages (Stage NI to II), a prolonged first feeding stage (Stage NIII) and intermediate duration of the remaining naupliar stages (Stages NIV to NVI). Short pre-feeding stages (NI and NII) and a prolonged first feeding stage (NIII) have also been observed in C. pacificus (Fernández 1979, Landry 1983), C. sinicus (Uye 1988), C. australis (Peterson \& Painting 1990), C. marshallae (Peterson 1986), C. finmarchicus (Hygum et al. 2000, Campbell et al. 2001) and C. helgolandicus (Bonnet et al. 2009). Rapid development of the first 2 naupliar stages is also common in many other copepod genera (Landry 1975, 1983, Miller et al. 1977, Peterson 2001), while rapid development of Stage NVI has been observed in C. marshallae (Peterson 1986) and C. helgolandicus (Thompson 1982). However, in our study Stage NV developed more rapidly than did NVI.

The prolonged duration of Stage NIII may be caused by a number of developmental events taking place during NIII (Marshall \& Orr 1955). Peterson (1986) noted that Calanus pacificus gained little weight during Stage NIII compared with other naupliar stages. This indicates that most of the energy taken up through the algal diet was not allocated for somatic growth. Instead, the energy might have been used for developing internal structures and to refuel the copepods after they have depleted their internally stored energy during Stages NI and NII.

The only study reporting development times of Calanus glacialis nauplii included rearing C. glacialis, C. hyperboreus and C. finmarchcius in the laboratory under food satiation at temperatures between 2 and $10^{\circ} \mathrm{C}$ (Corkett et al. 1986). Corkett et al. (1986) and McLaren et al. (1988) fitted these results to Belehradeks temperature function to determine development times in days $(D)$ as a function of temperature $(T)$ : 

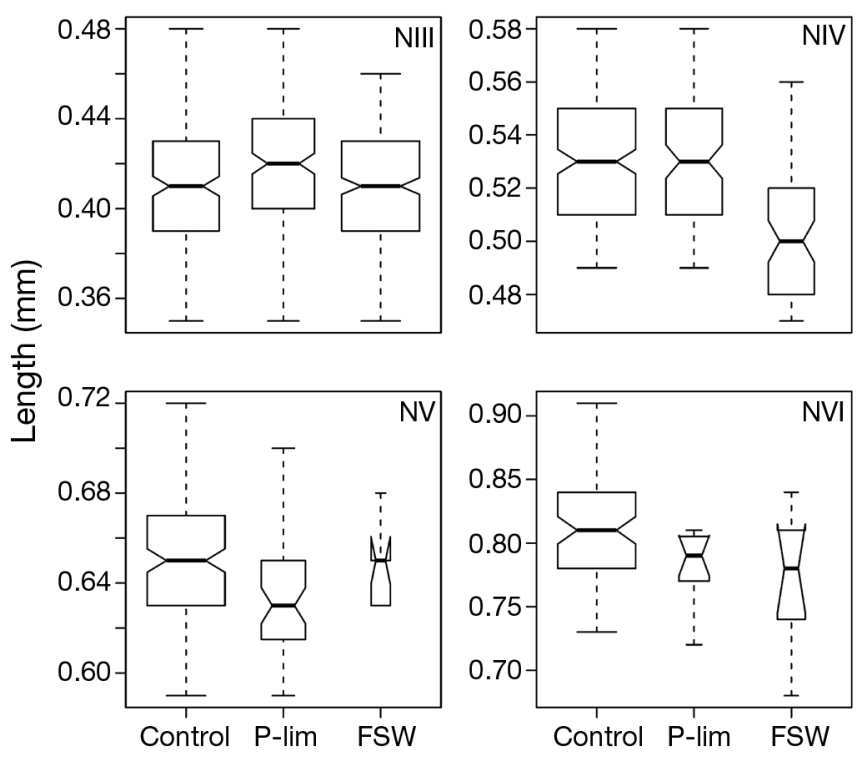

Fig. 2. Calanus glacialis. Boxplot of length $(\mathrm{mm})$ of nauplii Stages NIII to NVI in the 3 experimental treatments. Horizontal lines show the median. The bottom and top of the box show the 25th and 75th percentiles, respectively. Whiskers extend $1.5 \times$ the interquartile range of the sample. The boxes are drawn with widths proportional to the square-root values of the number of observations in the groups. Notches display the variability of the median between samples. The width of a notch is computed so that box plots whose notches do not overlap have different medians (Chambers et al. 1983). P-lim: phosphate limited; FSW: filtered sea water

$$
D=8882(T-13.04)^{-2.05}
$$

Using this function to calculate development time from hatching to Stage CI of C. glacialis results in a development time of $56 \mathrm{~d}$ at $-1.2^{\circ} \mathrm{C}$ (Fig. 3), which is $5 \mathrm{~d}$ longer than the observed median development time in our study for the control.

Compared with the 2 other Calanus species commonly found in the North Atlantic and Arctic waters, i.e. C. finmarchicus and C. hyperboreus, C. glacialis develops faster, especially at low temperatures (Fig. 3). At $-1.2^{\circ} \mathrm{C}, C$. glacialis develops $15 \mathrm{~d}$ faster than $C$. hyperboreus, and 13 to $20 \mathrm{~d}$ faster than C. finmarchicus (Fig. 3). Being able to develop fast despite low temperatures is a necessary adaptation to living in a cold climate with highly seasonal food supply. Thompson (1982) suggested that populations from cold areas develop more rapidly at lower temperatures and more slowly at higher temperatures than do populations from temperate regions. This is supported by Cook et al. (2007), who compared model predictions of stage duration of $C$. finmarchicus and C. helgolandicus, another congener Calanus species in the North Atlantic. The main distribution area of C. helgolandi-

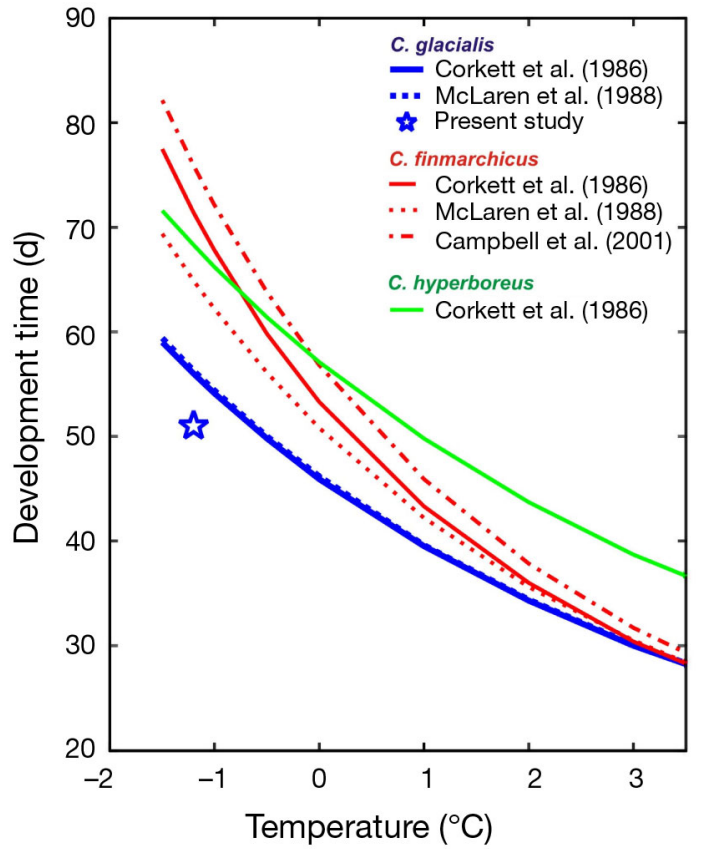

Fig. 3. Calanus spp. Temperature-dependent developmental time of 3 northern species from hatching to Stage CI based on Belehradek's temperature functions fitted to data from Corkett et al. (1986) for C. glacialis and C. hyperboreus, McLaren et al. (1988) for C. glacialis and C. finmarchicus, and Campbell et al. (2001) for C. finmarchicus. Development time from Campbell et al. (2001) is from egg to CI. Star indicates the development time observed in the present study

cus overlaps with that of $C$. finmarchicus but extends farther south into the North Atlantic and into the Mediterranean Sea. When exposed to the same temperature $\left(9\right.$ to $\left.12^{\circ} \mathrm{C}\right), \mathrm{C}$. finmarchicus developed faster than C. helgolandicus. Cook et al. (2007) also suggest that $C$. helgolandicus may be more sensitive to low food concentrations than C. finmarchicus. C. finmarchicus can reproduce at subzero temperatures (Hirche 1990, Hirche et al. 1997, Niehoff 2007) and although not as food sensitive as C. helgolandicus, it is still more dependent on food supply for reproduction than C. glacialis (Niehoff et al. 2002).

If the faster development of Calanus glacialis in comparison to $C$. finmarchicus reflects an adaptation to living in a cold climate with a highly seasonal food supply, this should also apply to $C$. hyperboreus, a true Arctic species that is even more adapted to high arctic conditions (Conover \& Huntley 1991, Falk-Petersen et al. 2009). C. hyperboreus is the largest of these 3 species. C. hyperboreus accumulates large lipid reserves and can reproduce independently of the spring bloom, fuelling egg and early naupliar development (Stages NI to III) most probably by lipid reserves (Hirche 1997, Niehoff 2007). However, apart from the study by Corkett et al. (1986), which indicates slower development 
Table 6. Calanus spp. Length distribution (mm) of total length of nauplii of North Atlantic and Arctic Calanus species. nd: no data

\begin{tabular}{|c|c|c|c|c|c|c|c|c|}
\hline \multirow{2}{*}{ Species } & \multirow[b]{2}{*}{ NI } & \multirow[b]{2}{*}{ NII } & \multicolumn{2}{|c|}{ - Naupliar stage } & \multirow[b]{2}{*}{ NV } & \multirow[b]{2}{*}{ NVI } & \multirow{2}{*}{ Region } & \multirow[t]{2}{*}{ Source } \\
\hline & & & NIII & NIV & & & & \\
\hline C. glacialis ${ }^{\mathrm{a}}$ & $<0.24$ & $0.25-0.34$ & $0.35-0.47$ & $0.48-0.58$ & $0.59-0.72$ & $>0.725$ & Svalbard & Present study \\
\hline C. finmarchicus ${ }^{\mathrm{b}}$ & 0.22 & 0.27 & 0.4 & 0.48 & 0.55 & 0.61 & North Sea & Ogilvie (1953) \\
\hline C. finmarchicus ${ }^{\mathrm{c}}$ & 0.172 & 0.209 & 0.266 & 0.402 & 0.52 & 0.635 & Norwegian Fjords & Hygum et al. (2000) \\
\hline C. finmarchicus ${ }^{\mathrm{d}}$ & nd & nd & 0.273 & 0.398 & 0.512 & 0.74 & Norwegian Fjords & Hygum et al. (2000) \\
\hline C. hyperboreus ${ }^{\mathrm{a}}$ & nd & nd & nd & $0.40-0.55$ & $0.5-0.68$ & $0.6-0.8$ & Norwegian Fjords & Sømme (1934) \\
\hline
\end{tabular}

than observed in C. glacialis, little is known about the naupliar development in C. hyperboreus.

\section{Naupliar sizes}

The 3 Calanus species that co-occur in the North Atlantic Ocean and Arctic Sea (C. finmarchicus, C. glacialis and C. hyperboreus) are very similar morphologically and differ mainly in size. Older copepodite stages (Stages CIV to CVI) of C. hyperboreus are easily distinguished by an acute spine at the last thoracic segment. However, the morphological differentiation of C. finmarchicus and C. glacialis copepodite stages involves tedious microscopy work. It has therefore become common practice to distinguish between these species, as well as younger copepodites of C. hyperboreus, by use of size classes. While a number of studies report size classes for copepodite stages of Calanus from different regions (Unstad \& Tande 1991, Hirche et al. 1994, Kwasniewski et al. 2003, Daase \& Eiane 2007), most studies usually do not distinguish between nauplii of the 3 species. Data on size distribution of Calanus nauplii are therefore scarce and to our knowledge this is the first study to establish size classes for the naupliar stages of C. glacialis.

Compared with the nauplii of other Calanus species, C. glacialis nauplii are, as expected, larger than C. finmarchicus nauplii (Table 6). However, our C. glacialis naupliar sizes are similar to the naupliar sizes determined for C. hyperboreus by Sømme (1934). Data from Sømme (1934) are from the Norwegian Sea where $C$. hyperboreus has a shorter life cycle than in Arctic waters (Broms et al. 2009). However, it is unknown whether that implies that $C$. hyperboreus are smaller in these areas, which could explain the overlap in naupliar size with that of $C$. glacialis in our study. Clear differences in egg size exist between the 3 Calanus species (Sømme 1934, McLaren 1966, Koga 1968, McLaren et al. 1969); thus, we would have expected a clearer trend in naupliar sizes. There is certainly a need for more data on the naupliar sizes of C. hyper- boreus to distinguish between nauplii of this species and C. glacialis in order to gain more insight into differences in life history strategies of the different Calanus species (such as time of reproduction) from field data. However, there seems to be a large overlap in naupliar sizes between all 3 Calanus species; thus, size may not be a suitable criteria for distinguishing between nauplii of the 3 species, whereas molecular methodology may provide more reliable means of taxonomic discrimination (Lindeque et al. 1999, Kiesling et al. 2002, Lindeque et al. 2006).

\section{Effect of food quality and quantity on naupliar development}

In the present study we tested the effects of food quality on naupliar development. Even when the quantity of digestible $\mathrm{C}$ is high, growth can be limited by deficiencies in essential elements (e.g. P and N) or biochemical compounds (e.g. essential fatty acids) (Hessen et al. 2002, 2004, Klein Breteler et al. 2005).

Nauplii of Calanus glacialis developed best under 'normal' food conditions (control). Not surprisingly nauplii kept without food supply in filtered seawater developed slowly and experienced high mortality. Suboptimal feeding conditions can increase development time in nauplii and copepodite stages of calanoid copepods and lead to higher variability in development time between individuals (Mullin \& Brooks 1970a, Vidal 1980a,b, Lopez 1996, Campbell et al. 2001). In our study Stage NIII survived for a long time under starvation; some individuals developed to Stage NIV and a few individuals even developed to NVI. Cook et al. (2007) reported that survival of starved nauplii of $C$. helgolandicus and $C$. finmarchicus decreased as temperature increased (temperature range, 12 to $15^{\circ} \mathrm{C}$ ) and explained that this is a result of a reduced metabolic rate at lower temperatures, which leads to higher survival at lower temperatures. Peterson (1986) suggested that Stage NIII might be able to survive and develop on internal energy supplies 
when food was scarce. Our observations indicate that Stage NIII nauplii of C. glacialis have enough energy reserves to develop under scarce food conditions even though it takes more time and nauplii become smaller in size. This may reflect an adaptation to Arctic conditions where the onset of the spring bloom is unpredictable and feeding conditions may not be optimal when Stage NIII is reached. For example, the subArctic calanoid copepod Neocalanus cristatus is able to develop to Stage CI without feeding (Saito \& Tsuda 2000).

Nutrient limitation can cause a decrease in algae PUFA content (Reitan et al. 1994, Klein Breteler et al. 2005). This has been attributed to the fact that algae start to produce storage (neutral) lipids (mainly triacylglycerols with a high amount of saturated fatty acids [SFA]) when their physiological conditions deteriorate instead of investing in growth, and thus polar lipids. In the present study, the growth of algal cultures in the laboratory under P-lim was successful insofar as the algal cultures used for the P-lim treatment had significantly lower proportions of PUFA than those used for the control treatment, as well as significantly higher $\mathrm{C}: \mathrm{N}$ and C:P ratios. However, the PUFA content in Plim algae was still relatively high and comparable with what was found in natural algal assemblages during late-bloom situations (Leu et al. 2006). In comparison, the high PUFA levels in the control treatment were as high as during pre-bloom conditions when the PUFA level is at its highest in natural algal assemblages (Leu et al. 2006). For the C:N:P stoichiometry, however, larger differences among treatments were found, and particularly for C:P (Table 2). Both $\mathrm{N}$ and $\mathrm{P}$ are crucial for protein synthesis and thus growth rate (Hessen et al. 2007). Although P-lim culture was grown under much lower $\mathrm{P}$ concentrations than the control, the 2 algal cultures had comparable $\mathrm{P}$ concentrations. However, a desynchronized uptake of $\mathrm{C}$ and $\mathrm{P}$ in the $\mathrm{P}$-lim algal culture occurred owing to the nutrient imbalance, causing up to 3 times higher C:P ratios in P-lim compared with the control treatment. This was most probably a result of an accumulation of C-rich storage compounds such as lipids and/or starch in the P-lim algal cells (Berman-Frank \& Dubinsky 1999), which the 2-fold higher lipid content in P-lim versus the control confirmed. Primary producers may exhibit a highly flexible cell stoichiometry with C:P ratios spanning more than an order of magnitude (Andersen 1997). In comparison, metazoan herbivores have a much tighter regulation of their stoichiometry. If the C:P ratio of the algal food increases beyond the threshold for balanced net intake of $\mathrm{C}$ relative to $\mathrm{P}$, growth efficiency in grazers in terms of $C$ will decline (Hessen 1992, Sterner \& Hessen 1994). The C:P or C:N ratios of autotrophs are commonly far below those of their grazers in both ter- restrial and aquatic ecosystems (Elser et al. 2000), and an increasing share of gross ingested $\mathrm{C}$ cannot be utilized for balanced somatic growth in consumers (Hessen 1992, Hessen \& Faafeng 2000).

In the present study, nauplii fed with P-lim algae developed at the same speed as those fed the control algae, but the mortality was much higher for the P-lim treatment. Little is known about the effect of P-limited food on the development of marine copepods. However, high mortalities of nauplii have also been observed in the freshwater copepod Diaptomus clavipes reared on an algal diet with high C:P content (Villar-Argaiz \& Sterner 2002). Villar-Argaiz \& Sterner (2002) found a more pronounced difference in development time in late naupliar stages (Stage NV and NVI) and in particular in the earlier copepodite stages (Stages CI and CII), in which the diet with a high C:P ratio increased development time considerably. Furthermore, in their study, copepods fed on algae grown under low $\mathrm{P}$ concentrations failed to develop beyond Stage CII. However, the C:P ratios of their P-deficient algal food were an order of magnitude higher than ours. Villar-Argaiz \& Sterner (2002) suggest that failure to develop to adulthood under P limitation may be due to ontogenetic differences in the $\mathrm{P}$ content of copepods, which may make certain developmental stages more sensitive to lack of P (see also Carrillo et al. 2001), or that the lack of certain PUFAs may be blocking the development of moulting processes at stages where the demand is high. How far this is applicable to Calanus glacialis is uncertain. Elemental stoichiometric studies of the freshwater calanoid copepod Mixodiaptomus laciniatus showed that the relative $\mathrm{P}$ content was higher in nauplii versus copepodites, which suggests that for calanoid copepods, nauplii may be more sensitive to high C:P ratios than are copepodites (Carrillo et al. 2001). Future studies investigating how food with high nutrient imbalance affects development time of C. glacialis beyond Stage NVI is thus also of great interest.

\section{Mortality}

The nauplii in our study experienced high mortality, with $78 \%$ of the individuals from the control treatment and over $95 \%$ from the other 2 treatments dying during the course of the experiment. These mortality rates were much higher than what was observed in other studies that reared Calanus species from hatching to Stage CI. For example, Paffenhöfer (1976) reported 2.8 to $33.6 \%$ mortality for C. helgolandicus/pacificus, Lopez (1991) observed 6 to $22 \%$ mortality in C. pacificus and Cook et al. (2007) reported 43 to $53 \%$ mortality for C. finmarchicus. However, C. helgolandicus 
reared under high or low food concentration experienced mortalities of up to $75 \%$ and $90 \%$, respectively (Cook et al. 2007), and our mortality for starved nauplii are similar to what Cook et al. (2007) observed for starved C. helgolandicus (>92\%). Furthermore, our daily per capita mortality rates are similar to what Lopez (1991) observed for nauplii (Stages NIII to NVI) of $C$. pacificus ( 0 to $0.2 \mathrm{~d}^{-1}$ ) and they are lower than the per capita daily mortality rates of nauplii of $C$. helgolandicus/pacificus in natural population (0.06 to $0.65 \mathrm{~d}^{-1}$; mean, $0.28 \mathrm{~d}^{-1}$ ) (Mullin \& Brooks 1970b).

In general, those studies that observed lower mortalities than in the present study had reared Calanus species at much higher temperatures $\left(8\right.$ to $\left.15^{\circ} \mathrm{C}\right)$ than we $\operatorname{did}\left(-1.2^{\circ} \mathrm{C}\right)$ (Paffenhöfer 1976, Lopez 1996, Cook et al. 2007). However, it seems unlikely that this may have caused higher mortalities, since subzero temperatures reflect the natural environment of $C$. glacialis. At this stage, no data from natural populations are available that may indicate that C. glacialis has a generally higher mortality than temperate calanoid copepods. Furthermore, laboratory studies that used different temperatures to rear Calanus spp. showed that low temperatures may suppress development time, but not survival (Cook et al. 2007).

Since temperature has an effect on development time (Corkett et al. 1986, Cook et al. 2007), Calanus spp. reared at higher temperatures developed faster; thus, those experiments were conducted for a shorter period of time (8 to $21 \mathrm{~d}$, Lopez 1996, Cook et al. 2007). In our study $65.8,81$ and $73 \%$ of the nauplii had already died after $21 \mathrm{~d}$ in the control, P-lim and FSW treatments, respectively. Consequently, the rate of mortality slowed down later in the experiment. Thus, the long duration of our experiment is probably not the reason for the high mortalities observed in the present study.

In contrast to other studies (Lopez 1991, Cook et al. 2007), we did not sacrifice parts of the individuals on a regular basis, rather all nauplii were returned to their experimental bottles after removing them to count and photograph them and to renew the water. Lopez (1991) noted from preliminary experiments that transferring nauplii daily to fresh food suspensions resulted in higher mortalities; therefore, in the present study, food was replenished every second day instead. Thus, we cannot rule out that our experimental approach may have caused higher mortalities. We handled the nauplii with great care by gently pouring them out, keeping them submerged in water at all times in cold surroundings, and keeping them out of their bottle for no longer than $30 \mathrm{~min}$ at a time. Also, since only some of the replicates were selected for taking digital photographs every second day, individuals in a replicate were only exposed to the longer photographing process every fourth or sixth day.
We observed differences in the behaviour of the nauplii between the 3 treatments, indicating that the different treatments had an effect on the individuals. Nauplii from the control treatment were generally much more active and lively than those in the other 2 treatments, in which the nauplii were barely moving. Some of the nauplii appeared almost dead and did not respond to gentle tactile stimulations. In particular, at the beginning of the experiment, before we became aware of this behaviour, some of these individuals may have been mistaken for being dead instead of being still alive but inactive, which may have biased the mortality estimates.

In summary, we conclude that starvation increased development time and mortality, indicating that Calanus glacialis most probably requires additional food supply during naupliar development and cannot develop on lipid reserves alone. The effect of poor food quality (low PUFA and high elemental ratios) was not unequivocal, and further studies are needed to elucidate the effect of poor food quality on naupliar development and to determine how far the deterioration of the environment (decrease of the food quality) may contribute to population decline by reducing the number of developed nauplii.

Acknowledgements. Thanks to H. C. Eilertsen for providing the algal cultures, G. Johnson and students for sampling copepods, and E. Leu for helpful guidance in culturing algae of different food qualities. We are grateful to M. Reigstad, University of Tromsø, and D. Hessen, University of Oslo, for the stoichiometrical analyses of our algae cultures. This study was funded by the Norwegian Research Council (Norwegian IPY project CLEOPATRA, project no. 178766/S30) and EUROCEANS, Network of Excellence funded by the European Commission (contract 511106-2, PostDoc Collaboration fellowship for D.M.).

\section{LITERATURE CITED}

Ackman RG (1989) Marine biogenic lipids, fats and oils, Vol 1. CRC Press, Boca Raton, FL

Aksnes DL, Miller CB, Ohman MD, Wood SN (1997) Estimation techniques used in studies of copepod population dynamics - a review of underlying assumptions. Sarsia 82:279-296

Andersen T (1997) Grazers as sources and sinks for nutrients. Ecol Ser 129. Springer-Verlag, New York, NY

Arnkvaern G, Daase M, Eiane K (2005) Dynamics of coexisting Calanus finmarchicus, Calanus glacialis and Calanus hyperboreus populations in a high-Arctic fjord. Polar Biol 28:528-538

> Berman-Frank I, Dubinsky Z (1999) Balanced growth in aquatic plants: myth or reality? Phytoplankton use the imbalance between carbon assimilation and biomass production to their strategic advantage. Bioscience 49:29-37

Blachowiak-Samolyk K, Søreide JE, Kwasniewski S, Sundfjord A, Hop H, Falk-Petersen S, Hegseth EN (2008) Hydrodynamic control of mesozooplankton abundance 
and biomass in northern Svalbard waters $\left(79-81^{\circ} \mathrm{N}\right)$. Deep-Sea Res II 55:2210-2224

Bonnet D, Harris RP, Yebra L, Guilhaumon F, Conway DVP, Hirst AG (2009) Temperature effects on Calanus helgolandicus (Copepoda: Calanoida) development time and egg production. J Plankton Res 31:31-44

Brett MT, Müller-Navarra DC (1997) The role of highly unsaturated fatty acids in aquatic food web processes. Freshw Biol 38:483-499

Broms C, Melle W, Kaartvedt S (2009) Oceanic distribution and life cycle of Calanus species in the Norwegian Sea and adjacent waters. Deep-Sea Res II 56:1910-1921

Campbell RG, Wagner MM, Teegarden GJ, Boudreau CA, Durbin EG (2001) Growth and development rates of the copepod Calanus finmarchicus reared in the laboratory. Mar Ecol Prog Ser 221:161-183

Carotenuto Y, Ianora A, Buttino I, Romano G, Miralto A (2002) Is postembryonic development in the copepod Temora stylifera negatively affected by diatom diets? J Exp Mar Biol Ecol 276:49-66

Carrillo P, Villar-Argaiz M, Medina-Sanchez JM (2001) Relationship between N:P ratio and growth rate during the life cycle of calanoid copepods: an in situ measurement. J Plankton Res 23:537-547

Chambers JM, Cleveland WS, Kleiner B, Tukey PA (1983) Graphical methods for data analysis. Wadsworth, Belmont, CA

Christie WW (1982) Lipid analysis. Pergamon Press, New York, NY

> Conover RJ (1988) Comparative life histories in the genera Calanus and Neocalanus in high latitudes of the northern hemisphere. Hydrobiologia 167-168:127-142

Conover RJ, Huntley M (1991) Copepods in ice-covered seas - distribution, adaptations to seasonally limited food, metabolism, growth patterns and life cycle strategies in polar seas. J Mar Res 2:1-41

Cook KB, Bunker A, Hay S, Hirst AG, Speirs DC (2007) Naupliar development times and survival of the copepods Calanus helgolandicus and Calanus finmarchicus in relation to food and temperature. J Plankton Res 29:757-767

Corkett CJ, McLaren IA, Sevigny JM (1986) The rearing of the marine calanoid copepods Calanus finmarchicus (Gunnerus), C. glacialis Jaschnov and C. hyperboreus Kroyer with comment on the equiproportional rule. In: Schriever G, Schminke HK, Shih CT (eds) Syllogeus 58. Proc 2nd Int Conf Copepoda 13-17 August, Ottawa. The National Museum of Canada, Ottawa, p 539-546

> Daase M, Eiane K (2007) Mesozooplankton distribution in northern Svalbard waters in relation to hydrography. Polar Biol 30:969-981

Elser JJ, Sterner RW, Gorokhova E, Fagan WF and others (2000) Biological stoichiometry from genes to ecosystems. Ecol Lett 3:540-550

Falk-Petersen S, Mayzaud P, Kattner G, Sargent J (2009) Lipids and life strategy of Arctic Calanus. Mar Biol Res 5:18-39

Fernáandez F (1979) Nutrition studies in the nauplius larva of Calanus pacificus (Copepoda, Calanoida). Mar Biol 53: 131-147

Folch J, Lees M, Sloane Stanley GH (1957) A simple method for isolation and purification of total lipids from animal tissue. J Biol Chem 226:497-509

Guillard RRL (1978) Counting slides. In: Soumia A (ed) Phytoplankton manual. UNESCO, Paris, p 182-189

> Hart RC (1990) Copepod postembryonic durations pattern and predictability: the realities of isochronal and equiproportional development and trends in the copepodidnaupliar duration ratio. Hydrobiologia 206:175-206
Hessen DO (1992) Nutrient element limitation of zooplankton production. Am Nat 140:799-814

Hessen DO, Faafeng BA (2000) Elemental ratios in freshwater seston; implications for community structure and energy transfer in food webs. Arch Hydrobiol (Spec Issue Adv Limnol) 55:349-363

> Hessen DO, Faerovig PJ, Andersen T (2002) Light, nutrients, and $\mathrm{P}: \mathrm{C}$ ratios in algae: grazer performance related to food quality and quantity. Ecology 83:1886-1898

Hessen DO, Agren GI, Anderson TR, Elser JJ, De Ruiter PC (2004) Carbon sequestration in ecosystems: the role of stoichiometry. Ecology 85:1179-1192

Hessen DO, Jensen TC, Kyle M, Elser JJ (2007) RNA responses to $\mathrm{N}$ - and P-limitation; reciprocal regulation of stoichiometry and growth rate in Brachionus. Funct Ecol 21:956-962

Hirche HJ (1990) Egg-production of Calanus finmarchicus at low temperature. Mar Biol 106:53-58

Hirche HJ (1997) Life cycle of the copepod Calanus hyperboreus in the Greenland Sea. Mar Biol 128:607-618

Hirche HJ, Kattner G (1993) Egg-production and lipid-content of Calanus gacialis in spring: indication of a fooddependent and food-independent reproductive mode. Mar Biol 117:615-622

> Hirche HJ, Kosobokova K (2003) Early reproduction and development of dominant calanoid copepods in the sea ice zone of the Barents Sea-need for a change of paradigms? Mar Biol 143:769-781

> Hirche HJ, Hagen W, Mumm N, Richter C (1994) The northeast water polynya, Greenland Sea. III. Mesozooplankton and macrozooplankton distribution and production of dominant herbivorous copepods during spring. Polar Biol 14:491-503

Hirche HJ, Meyer U, Niehoff B (1997) Egg production of Calanus finmarchicus: effect of temperature, food and season. Mar Biol 127:609-620

Hirst AG, Lampitt RS (1998) Towards a global model of in situ weight-specific growth in marine planktonic copepods. Mar Biol 132:247-257

Holm-Hansen O, Rieman B (1978) Chlorophyll a determination: improvement of the methodology. Oikos 30:438-447

Hop H, Falk-Petersen S, Svendsen H, Kwasniewski S, Pavlov V, Pavlova O, Søreide JE (2006) Physical and biological characteristics of the pelagic system across Fram Strait to Kongsfjorden. Prog Oceanogr 71:182-231

> Huntley ME, Ciminiello P, Lopez MDG (1987) Importance of food quality in determining development and survival of Calanus pacificus (Copepoda, Calanoida). Mar Biol 95: 103-113

> Hygum BH, Rey C, Hansen BW (2000) Growth and development rates of Calanus finmarchicus nauplii during a diatom spring bloom. Mar Biol 136:1075-1085

Ianora A, Miralto A, Poulet SA, Carotenuto Y and others (2004) Aldehyde suppression of copepod recruitment in blooms of a ubiquitous planktonic diatom. Nature 429: 403-407

> Jónasódttir SH (1994) Effects of food quality on the reproductive success of Acartia tonsa and Acartia hudsonica: laboratory observations. Mar Biol 121:67-81

Jónasdóttir SH, Trung NH, Hansen F, Gartner S (2005) Egg production and hatching success in the calanoid copepods Calanus helgolandicus and Calanus finmarchicus in the North Sea from March to September 2001. J Plankton Res 27:1239-1259

Jónasdóttir SH, Visser AW, Jespersen C (2009) Assessing the role of food quality in the production and hatching of Temora longicornis eggs. Mar Ecol Prog Ser 382:139-150 
Kiesling TL, Wilkinson E, Rabalais J, Ortner PB, McCabe MM, Fell JW (2002) Rapid identification of adult and naupliar stages of copepods using DNA hybridization methodology. Mar Biotechnol 4:30-39

Klein Breteler WCM, Schogt N, Rampen S (2005) Effect of diatom nutrient limitation on copepod development: role of essential lipids. Mar Ecol Prog Ser 291:125-133

Koga F (1968) On the pelagic eggs of Copepoda. J Oceanogr Soc Jpn 24:16-20

Koski M, Breteler WK, Schogt N (1998) Effect of food quality on rate of growth and development of the pelagic copepod Pseudocalanus elongatus (Copepoda, Calanoida). Mar Ecol Prog Ser 170:169-187

> Kosobokova KN, Hanssen H, Hirche HJ, Knickmeier K (1998) Composition and distribution of zooplankton in the Laptev Sea and adjacent Nansen Basin during summer, 1993. Polar Biol 19:63-76

Kwasniewski S, Hop H, Falk-Petersen S, Pedersen G (2003) Distribution of Calanus species in Kongsfjorden, a glacial fjord in Svalbard. J Plankton Res 25:1-20

Landry MR (1975) Relationship between temperature and development of life stages of the marine copepod Acartia clausi Giesbr. Limnol Oceanogr 20:854-857

Landry MR (1983) The development of marine calanoid copepods with comment on the isochronal rule. Limnol Oceanogr 28:614-624

Lee RF (1974) Lipid-composition of copepod Calanus hyperboreas from Arctic Ocean. Changes with depth and season. Mar Biol 26:313-318

Lee RF (1975) Lipids of Arctic zooplankton. Comp Biochem Physiol B Biochem Mol Biol 51:263-266

> Lee RF, Hagen W, Kattner G (2006) Lipid storage in marine zooplankton. Mar Ecol Prog Ser 307:273-306

> Leu E, Falk-Petersen S, Kwasniewski S, Wulff A, Edvardsen $\mathrm{K}$, Hessen DO (2006) Fatty acid dynamics during the spring bloom in a high Arctic fjord: importance of abiotic factors versus community changes. Can J Fish Aquat Sci 63:2760-2779

Levinsen H, Turner JT, Nielsen TG, Hansen BW (2000) On the trophic coupling between protists and copepods in Arctic marine ecosystems. Mar Ecol Prog Ser 204:65-77

Lindeque PK, Harris RP, Jones MB, Smerdon GR (1999) Simple molecular method to distinguish the identity of Calanus species (Copepoda: Calanoida) at any developmental stage. Mar Biol 133:91-96

> Lindeque PK, Hay SJ, Heath MR, Ingvarsdottir A, Rasmussen J, Smerdon GR, Waniek JJ (2006) Integrating conventional microscopy and molecular analysis to analyse the abundance and distribution of four Calanus congeners in the North Atlantic. J Plankton Res 28:221-238

Lopez MDG (1991) Molting and mortality depend on age and stage in naupliar Calanus pacificus: implication for developement time in field cohorts. Mar Ecol Prog Ser 75:79-89

Lopez MDG (1996) Effect of starvation on development and survivorship of naupliar Calanus pacificus (Brodsky). J Exp Mar Biol Ecol 203:133-146

MacDonald P, Pitcher J (1979) Age-groups from size-frequency data: a versatile and efficient method of analyzing distribution mixtures. J Fish Res Board Can 36:987-1001

Marshall SM, Orr AP (1955) The biology of a marine copepod (Calanus finmarchicus Gunnerus). Oliver \& Boyd, Edinburgh

McLaren IA (1966) Predicting devlopment rate of copepod eggs. Biol Bull (Woods Hole) 131:457-469

McLaren IA, Corkett CJ (1981) Temperature-dependent growth and production by a marine copepod. Can J Fish Aquat Sci 38:77-83
McLaren IA, Corkett CJ, Zillioux EJ (1969) Temperature adaptations of copepod eggs from the Arctic to the tropics. Biol Bull (Woods Hole) 137:486-493

> McLaren IA, Sevigny JM, Corkett CJ (1988) Body sizes, development rates, and genome sizes among Calanus species. Hydrobiologia 167-168:275-284

Miller CB, Johnson JK, Heinle DR (1977) Growth rules in marine copepod genus Acartia. Limnol Oceanogr 22: 326-335

Mullin MM, Brooks ER (1970a) Growth and metabolism of two planktonic, marine copepods as influenced by temperature and type of food. In: Steele $\mathrm{JH}$ (ed) Marine food chains. Oliver \& Boyd, Edinburgh, p 74-95

Mullin MM, Brooks ER (1970b) Part VII. Production of the planktonic copepod Calanus helgolandicus. In: Strickland JDH (ed) The ecology of the plankton off La Jolla, California, in the period April through September, 1967, Vol 17. University of California Press, Berkeley and Los Angeles, CA, p 89-104

> Niehoff B (2007) Life history strategies in zooplankton communities: the significance of female gonad morphology and maturation types for the reproductive biology of marine calanoid copepods. Prog Oceanogr 74:1-47

Niehoff B, Madsen SD, Hansen BW, Nielsen TG (2002) Reproductive cycles of three dominant Calanus species in Disko Bay, West Greenland. Mar Biol 140:567-576

Ogilvie H (1953) Copepod nauplii (I). Conseil International pour L'Exploration de la Mer Zooplankton Sheet 50. ICES, Copenhagen

Paffenhöfer GA (1976) Feeding, growth, and food conversion of marine planktonic copepod Calanus helgolandicus. Limnol Oceanogr 21:39-50

Peterson WT (1986) Development, growth, and survivorship of the copepod Calanus marshallae in the laboratory. Mar Ecol Prog Ser 29:61-72

> Peterson WT (2001) Patterns in stage duration and development among marine and freshwater calanoid and cyclopoid copepods: a review of rules, physiological constraints, and evolutionary significance. Hydrobiologia 453-454:91-105

> Peterson WT, Painting SJ (1990) Developmental rates of the copepods Calanus australis and Calanoides carinatus in the laboratory, with discussion of methods used for calculation of development time. J Plankton Res 12: 283-293

Pond D, Harris R, Head R, Harbour D (1996) Environmental and nutritional factors determining seasonal variability in the fecundity and egg viability of Calanus helgolandicus in coastal waters off Plymouth, UK. Mar Ecol Prog Ser 143: 45-63

Reitan KI, Rainuzzo JR, Olsen Y (1994) Effect of nutrient limitation on fatty acid and lipid content of marine mircoalgae. J Phycol 30:972-979

> Rey C, Harris R, Irigoien X, Head R, Carlotti F (2001) Influence of algal diet on growth and ingestion of Calanus helgolandicus nauplii. Mar Ecol Prog Ser 216:151-165

Saito H, Tsuda A (2000) Egg production and early development of the subarctic copepods Neocalanus cristatus, $N$. plumchrus and $N$. flemingeri. Deep-Sea Res I 47: 2141-2158

Sakshaug E, Johnsen G, Kristiansen S, von Quillfeldt C, Rey F, Slagstad D, Thingstad F (2009) Phytoplankton and primary production. In: Sakshaug E, Johnsen G, Kovacs K (eds) Ecosystem Barents Sea. Tapir Academic Press, Trondheim, p 167-208

Sargent JR, Falk-Petersen S (1988) The lipid biochemistry of calanoid copepods. Hydrobiologia 167-168:101-114 
Schoen S (1988) Cell counting. In: Lobban CS, Chapman DJ, Kremer BP (eds) Experimental phycology. A laboratory manual. Cambridge University Press, Cambridge, p 16-22

Scott CL, Kwasniewski S, Falk-Petersen S, Sargent JR (2000) Lipids and life strategies of Calanus finmarchicus, Calanus glacialis and Calanus hyperboreus in late autumn, Kongsfjorden, Svalbard. Polar Biol 23:510-516

Scott CL, Kwasniewski S, Falk-Petersen S, Sargent JR (2002) Species differences, origins and functions of fatty alcohols and fatty acids in the wax esters and phospholipids of Calanus hyperboreus, C. glacialis and C. finmarchicus from Arctic waters. Mar Ecol Prog Ser 235:127-134

Sokal RR, Rohlf FJ (1995) Biometry: the principles and practices of statistics in biological research. WH Freeman, New York, NY

Sømme JD (1934) Animal plankton of the Norwegian coast waters and the open sea I: production of Calanus finmarchicus (Gunnerus) and Calanus hyperboreus (Krøyer) in the Lofoten area. Fiskeridir Skr Ser Havunders 4:1-163

Søreide JE, Falk-Petersen S, Hegseth EN, Hop H, Carroll ML, Hobson KA, Blachowiak-Samolyk K (2008) Seasonal feeding strategies of Calanus in the high-Arctic Svalbard region. Deep-Sea Res II 55:2225-2244

Søreide JE, Leu E, Berge J, Graeve M, Falk-Petersen S (2010) Timing of blooms, algal food quality and Calanus glacialis

Editorial responsibility: Benni Hansen,

Roskilde, Denmark reproduction and growth in a changing Arctic. Glob Change Biol 16:3154-3163

Sterner RW, Hessen DO (1994) Algal nutrient limitation and the nutrition of aquatic herbivores. Annu Rev Ecol Syst 25: $1-29$

Thompson BM (1982) Growth and development of Pseudocalanus elongatus and Calanus sp. in the laboratory. J Mar Biol Assoc UK 62:359-372

> Unstad KH, Tande K (1991) Depth distribution of Calanus finmarchicus and C. glacialis in relation to environmental conditions in the Barents Sea. Polar Res 10:409-420

- Uye S (1988) Temperature-dependent development and growth of Calanus sinicus (Copepoda: Calanoida) in the laboratory. Hydrobiologia 167-168:285-293

Vidal J (1980a) Physio-ecology of zooplankton 1. Effects of phytoplankton concentration, temperature and body size on the growth-rate of Calanus pacificus and Pseudocalanus sp. Mar Biol 56:111-134

Vidal J (1980b) Physio-ecology of zooplankton 2. Effects of phytoplankton concentration, temperature, and body size on the development and molting rates of Calanus pacificus and Pseudocalanus sp. Mar Biol 56:135-146

- Villar-Argaiz M, Sterner RW (2002) Life history bottlenecks in Diaptomus clavipes induced by phosphorus-limited algae. Limnol Oceanogr 47:1229-1233

Submitted: January 12, 2010; Accepted: February 3, 2011 Proofs received from author(s): April 24, 2011 